\title{
IMPLEMENTATION OF ENERGY-SAVING INNOVATIONS AS THE MAIN DIRECTION OF DEVELOPMENT OF THE BUILDING MATERIALS INDUSTRY
}

\author{
Olga KUZINA \\ Plekhanov Russian University of Economics, Russian Federation \\ kuzina.olga.viktorovna@yandex.ru
}

\begin{abstract}
The value of the construction industry for green growth of the Russian economy is identified. The structure of the building materials industry, indicators of production volumes, share of exports and imports of construction materials are analysed. The main factors of high energy consumption in the construction industry are formed as a table. Main activities to modernise the building materials industry and "green" growth of the Russian economy as a whole are proposed. The urgency of formation of the mechanism of energysaving innovation application in the construction industry is justified. The methodology of management of the building materials industry development through the introduction of energy-saving innovations is proposed.
\end{abstract}

Keywords: Energy-saving innovations, energy consumption, building materials industry, "green" economy.

\section{INTRODUCTION}

Currently, forming a new model of the Russian economy is based on the principles of green growth to reduce energy consumption and improve national competitiveness. According to existing approaches among the major parameters that determine the energy efficiency of national economies, the energy intensity of gross domestic product is allocated. The rate of decline of this indicator shows the effectiveness of the energy saving policy of the state. The energy intensity of gross domestic product is defined as the ratio of the total energy consumption in the production of gross domestic product (Kuzina, 2014).

The modernisation basis of the economy based on technological innovations and the principles of energy efficiency is founded in the "Strategy of Innovative Development of the Russian Federation for the Period till 2020" (approved 2011), "Energy Strategy of Russia for the Period up to 2030" (approved 2009) and "Main Directions of Activity of the Russian Federation Government for the Period until 2018" (approved 2013) in terms of improving environmental and energy efficiency of the economy through the introduction of energy-saving innovation, ensuring green growth, adaptation of the economy to climate change.

Analysis of international experience shows that energy-saving innovation is the foundation of sustainable development of economy in the conditions of exhaustion of natural resources, growth of the cost of primary natural energy. At the same time, the use of energy-saving innovation in the economy is an important factor and a condition of competition. 
According to "Main Directions of Activities of the Russian Federation Government for the Period until 2018", approved on 31 January 2013, the formation of a new model of the Russian economy development in conditions of uncertainty and instability in the global economic system requires increasing national competitiveness and productivity, creation of conditions for effective development of domestic and foreign markets to solve the housing problem. At the same time, a new stage of technological development of the global economy dictates the need for a drastic strengthening of the innovation component of the Russian economy development, technological capabilities and increasing investments in areas such as new materials, nanotechnology, information technology, pharmaceuticals and biotechnology (Decree of the Russian Federation Government, 2013).

Not to mention the role of the construction industry as an important part of establishing a new model of the Russian economy development, solving social problems due to the mass construction of high-quality and affordable housing, objects of engineering and transport infrastructure, reconstruction of the housing stock. In these conditions, the building materials industry, on the one hand, must ensure the matching supply of production volumes with demand for domestic and foreign markets on the other hand, improve the quality, efficiency and sustainability of building materials to enhance national competitiveness in the global market.

\section{GENERAL REGULATIONS}

According to Fig. 1, energy consumption during creating construction products is distributed in two main stages - the production of building materials and the process of construction of objects. The indicator is approximately $23.5 \%$ of the estimated cost of construction and assembling works (Retrieved June 10, 2014 from the Ministry of regional development of the Russian Federation website).

"The Strategy of Development of the Building Materials Industry and Industrial Construction for the Period till 2020", approved by Order of Ministry of Regional Development of the Russian Federation as of 30 May 2011, No. 262, is aimed at creating conditions for innovative development of the construction industry, including modernisation of the building materials industry, and sustainable growth of the Russian economy as a whole.

Currently, the building materials industry includes, according to the Russian Classifier of Economic Activity Types, production in the section "Mining and Quarrying" and section D "Manufacturing". A more detailed structure of production is presented in Table 1 (Kuzina, 2014; Retrieved July 14, 2014 from the Federal state statistics service website). In addition, in capital construction products of other economic activities, including metallurgical, woodworking, chemical, pulp and paper complexes, are used.

The main products produced by the building materials industry include: cement, precast concrete structures and products, sheet glass, asbestos products, non-metallic building materials (crushed stone, gravel, sand), wall materials 
(ceramic and silicate bricks, blocks of cellular concrete), roofing and waterproofing materials, insulation materials made of mineral fibre and polymer materials, optical fibre (Retrieved June 10, 2014 from the Ministry of regional development of the Russian Federation website).

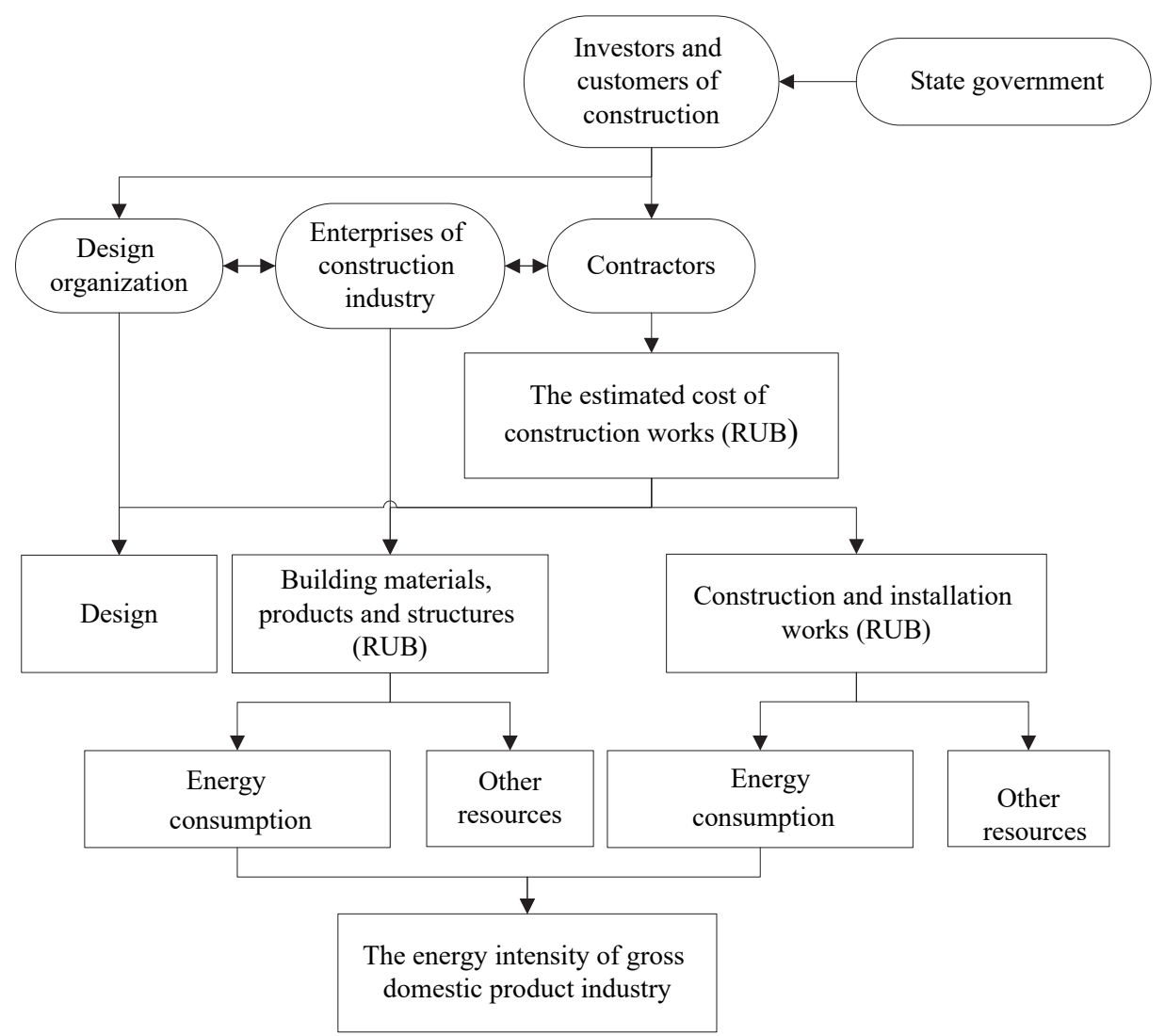

Fig. 1. The structure of products of the construction industry.

The consumption volume of basic building materials is relatively equal to the volume of production taking into account export and import operations. The main products of the building materials industry are imported in small numbers, and the share of domestic producers in terms of sales on the domestic market is $98-100 \%$. The most export-oriented material is asbestos, $50 \%$ of the production volume is exported (Retrieved June 14, 2015 from the Information construction portal website).

For other materials, the share of export in volume of their production is $5-14 \%$. The increase in the production of insulating materials made of mineral fibre and optical fibre is outstripping the growth of their consumption by $18 \%$, and the growth of cement consumption is outpacing production growth of $8 \%$, flat glass by $48.5 \%$ and asbestos cement products $-12.8 \%$. The lack of competitiveness of quality domestic glass production has allowed foreign producers to capture a significant share in the structure of glass consumption in the Russian market of building materials (Decree of the Ministry of regional development of the Russian Federation, 2011). 
The construction industry based on multi-disciplinary construction holding companies includes the design, construction and assembling companies, organisations - manufacturers of concrete products, structures and materials, the organisations of motor transport and mechanisation of construction. Organisations as holdings conduct a full construction volume of buildings, structures and infrastructure and send a profit to their own development. The state production base of such enterprises determines the development of city construction industry and ensures the planned volumes of housing, socio-cultural, industrial construction, engineering and transport infrastructure, as well as renovation projects.

Table 1. The Structure of the Building Materials Industry

\begin{tabular}{|l|l|}
\hline $\begin{array}{l}\text { Subsection CB (14) "Other Minerals } \\
\text { Mining" }\end{array}$ & $\begin{array}{l}\text { Subsection DI (26) "Manufacture of Other } \\
\text { Non-metallic Mineral Products" }\end{array}$ \\
\hline 14.1. Development of stone quarries & 26.1. Manufacture of glass and glass products \\
\hline $\begin{array}{l}\text { 14.11. Extraction of stone, including } \\
\text { marble, granite, sandstone }\end{array}$ & 26.3. Manufacture of ceramic tiles and slabs \\
\hline $\begin{array}{l}\text { 14.12. Quarrying of limestone, gypsum } \\
\text { and chalk }\end{array}$ & $\begin{array}{l}\text { 26.4. Manufacture of bricks, tiles and construction } \\
\text { products, in baked clay }\end{array}$ \\
\hline 14.13. The extraction of shale & 26.5. The production of cement, lime and plaster \\
\hline $\begin{array}{l}\text { 14.2. Extraction of gravel, sand and clay } \\
\text { and cement }\end{array}$ \\
\hline $\begin{array}{l}\text { 14.21. Development of gravel and sand } \\
\text { pits }\end{array}$ & $\begin{array}{l}\text { 26.8. Manufacture of other non-metallic mineral } \\
\text { products }\end{array}$ \\
\hline $\begin{array}{l}\text { 14.22. Mining of clay and kaolin } \\
\text { elsewhere classified }\end{array}$ & $\begin{array}{l}\text { 26.82.1. Production of processed asbestos fibre with } \\
\text { the basis of asbestos and products }\end{array}$ \\
\hline $\begin{array}{l}\text { 14.5. Other mining and quarrying not } \\
\text { and natural bitumen } \\
\text { products of similar materials }\end{array}$ \\
\hline $\begin{array}{l}\text { 14.50.2. Production of natural abrasives, } \\
\text { other non-metallic minerals } \text { stone, asbestos, mica, quartz and } \\
\text { classified }\end{array}$ & $\begin{array}{l}\text { 26.82.3. The production of bituminous mixtures } \\
\text { based on natural asphalt or bitumen, petroleum } \\
\text { bitumen, mineral tar or pitch used in road } \\
\text { construction and for insulation coatings }\end{array}$ \\
\hline insulation materials and products \\
\hline
\end{tabular}

Production of building materials, products and structures for the current period meets the needs of the construction industry and has a certain potential of production growth. However, production has a low energy efficiency and degree of production automation and, consequently, high production costs.

\section{PROBLEMS OF THE BUILDING MATERIALS INDUSTRY}

There are objective reasons for high energy consumption in the construction industry, including building materials industry: on the one hand, the imperfection of the existing legal, financial and price mechanism, weakly stimulating producers and consumers of energy to reduce fuel costs and energy, but, on the other hand, 
a low volume of new energy efficient technologies, equipment and materials, as well as the weakness of the information base market infrastructure in this area.

The main problems existing in the building materials industry are presented in Table 2 (Kuzina, 2014). The main factor influencing the overuse of energy resources is the high depreciation of capital equipment, which increases production costs and makes it less competitive in comparison with foreign analogues. Building materials enterprises use imported equipment, which adversely affects the return on these businesses and the cost of production.

Table 2. Factors of the High Energy Consumption in the Industry

\begin{tabular}{|c|c|c|}
\hline $\begin{array}{l}\text { The name } \\
\text { of the group } \\
\text { factors }\end{array}$ & The group & $\begin{array}{c}\text { Evaluation } \\
\text { of the } \\
\text { group } \\
\text { influence, } \\
\% \\
\end{array}$ \\
\hline \multirow{4}{*}{ Production } & $\begin{array}{l}\text { Technological backwardness of Russian building materials } \\
\text { industry from similar production of the leading world countries }\end{array}$ & \multirow{4}{*}{50} \\
\hline & $\begin{array}{l}\text { Physical deterioration of the basic production assets of } \\
\text { enterprises of building materials industry }\end{array}$ & \\
\hline & Low labour productivity in the industry & \\
\hline & $\begin{array}{l}\text { Low innovation activity of enterprises producing building } \\
\text { materials, products and structures }\end{array}$ & \\
\hline \multirow[t]{2}{*}{$\begin{array}{l}\text { Scientific and } \\
\text { technological }\end{array}$} & $\begin{array}{l}\text { Insufficiency of scientific research and experimental design } \\
\text { works on creation of new highly efficient technologies and } \\
\text { processes }\end{array}$ & \multirow[t]{2}{*}{15} \\
\hline & $\begin{array}{l}\text { Shortage of technical staff and mid-level workers and their low } \\
\text { level of qualification }\end{array}$ & \\
\hline Economic & $\begin{array}{l}\text { The lack of an adequate volume of own enterprises funds in the } \\
\text { construction industry and their access to contingent sources of } \\
\text { funding to conduct an effective investment policy }\end{array}$ & 20 \\
\hline \multirow{2}{*}{ Administrative } & $\begin{array}{l}\text { The inadequacy of the existing legal framework on energy } \\
\text { consumption, as well as creating conditions for the use of } \\
\text { industrial waste of related industries as raw material in the } \\
\text { building materials production }\end{array}$ & \multirow{2}{*}{15} \\
\hline & $\begin{array}{l}\text { Insufficient state support of the enterprises of the construction } \\
\text { industry in terms of innovation in the production process, } \\
\text { utilisation of fuel-containing waste as supplemental fuel in } \\
\text { industrial processes }\end{array}$ & \\
\hline
\end{tabular}

The amount of enterprise funds aimed at technical re-equipment of production is not more than 1-2\%. While production capacity is loaded with the industry average of $82 \%$, capacity of some enterprises does not exceed $65 \%$. $70 \%$ of enterprises of building materials industry have a degree of deterioration of $52 \%$ on average, and manufactured equipment for the building materials industry lags behind leading foreign counterparts by more than 25-30 years. As a result, the number of loss-making enterprises accounts for $25.5 \%$ of the total number of organisations. The high level of technological gap and physical depreciation of fixed assets, resulting in low productivity and weak innovation activity, requires a qualitative change in manufacturing processes (Kuzina, 2015). 
The development of new technologies is related to financial expenses in the implementation process and the instability of enterprise performance, such as return on assets associated with the efficiency level of fixed assets use, profitability, showing how much profit on each rouble is invested in organisation assets. These indicators are related to the level of investments assigned for modernisation and introduction of innovative technologies into production. If we consider the rate of return on assets in the dynamics, the growth ratio indicates improved efficiency of equipment use.

Enterprises need to increase investment by $20-30 \%$ to get the return on assets ratio to the level of $8-10 \%$ and to increase the level of production profitability by $20 \%$. In the implementation of innovative technologies, the return on assets ratio at $50 \%$ load is increased by $2-3$ times. The full enterprise capacity leads to maximum return on assets with insignificant increase of investments in innovation and increases profitability by $3-5$ times. This is due to the production increase and sales of new products on the market. However, under the condition of loss-making enterprises, even the high level of investments in the innovative technology does not increase the return on assets and increases profitability. Such enterprises require a complete reorganisation of production (Kuzina, 2015).

Modernisation of building materials industry should be directed to solving systemic problems of a structural nature:

- technological backwardness of the building materials industry from a similar production in the leading countries of the world;

- physical deterioration of the basic production assets of enterprises in the construction industry;

- low competitiveness of construction products, manufactured using energy intensive technologies on obsolete equipment;

- insufficient innovation activity of commercial structures.

\section{THE METHODOLOGY OF THE BUILDING MATERIALS INDUSTRY DEVELOPMENT}

Overcoming the challenges of building materials industry, according to the strategy, is envisaged due to the following events (Decree of the Ministry of regional development of the Russian Federation, 2011):

- creation of conditions for implementation of priority directions aimed at developing production of building materials, products and structures, expansion of their range, improvement of consumer properties and saturation of the market with modern, high-quality, competitive products, including the development of the engineering base for the production of energy efficient equipment for the building materials industry;

- formation of an economic measure complex for encouraging enterprises of building materials industry and related industrial complexes to improve the technical level of production, overcoming the technological backwardness of Russian industry from a similar production in leading countries and establish a civilized market of competitive products; 
- ensuring compliance of the production technological processes, operation of equipment for production of building materials with environmental safety requirements.

In these conditions, the formation mechanism of application of energy-saving innovations contributes to improving production efficiency, quality and competitiveness of products, reducing the number of unprofitable enterprises, achieving the production of innovative and energy-efficient materials and designs, improved construction quality, resource savings and lower costs for construction, reconstruction, maintenance and repair of buildings and structures.

In addition, an important reserve for the development of building materials industry is the involvement of technogenic deposits, comprehensive utilisation of production waste to create products of construction industry, which generally have a positive impact on the environment improvement, the elimination of accumulated environmental damage.

The management methodology of building materials industry development through the introduction of energy-saving innovations should include (Kuzina, 2015):

- the development of theoretical approaches, clarification of the conceptual apparatus in the field of Economics of green building, the building materials industry through the application of energy saving and environmental innovation;

- the assessment of the potential of energy-efficient innovation application in building materials industry;

- the justification of the role of technological fields as the resource base for industry development;

- the formation of institutional mechanisms for the development of green building in the field of building materials industry, providing implementation of energy-saving innovations in the economy;

- the development of conceptual provisions, guidelines to the evaluation of production competitiveness of building materials enterprises subject to the requirements of their environmental friendliness and energy efficiency;

- the development of methodical recommendations on project management of innovation implementation in the construction industry, including environmental and energy factors;

- the formation of the organisational-economic mechanism of development of green economy in relation to the building materials industry, including: (a) the assessment of the interests of participants of investment and construction project (investors, construction companies, construction industry, consumers) with the development of building materials industry based on the principles of resource and energy saving; b) methods of economic stimulation of production and use of energy-efficient and ecofriendly materials and technologies in construction; b) justification of progressive financing forms for the implementation of energy-saving innovations; d) assessment of the effects (economic, social, environmental, energy, climate) by the introduction of energy-saving innovations, as well as the definition of environmental damage, and 
reduction of the load on the environment from industrial enterprises of building materials; e) improving the system of environmental-economic accounting of resource and energy consumption taking into account the reflection of energy-saving innovations;

- the development of recommendations on environmental and energy factors to evaluate real estate and efficiency of projects in the implementation of energy-saving innovations in the building materials industry;

- the study areas for the application of energy-saving innovations in the building materials industry as a multiplier of green growth economy.

\section{RESULTS}

Institutional framework and mechanisms of the developed "green" building will allow us to introduce energy and environmental innovations in production, to stimulate innovative development of the economy, which in general is aimed at solving high-priority social and environmental problems.

Quantitative and qualitative assessment of the potential of energy and environmental innovation in the building materials industry will allow us to substantiate the plans and strategy of building materials industry development through the application of innovations to reduce the consumption of primary natural resources and energy, to prevent pollution damage, to minimise ecological and economic risks.

The use of energy and environmental innovation in construction is a multiplier of growth in related areas and activities (transport, housing and utilities) that will allow solving a number of public, social challenges of the country's development in the future.

Methodology of ecological and economic management of energy-efficient innovation in the building materials industry will contribute to the modernisation and technological development of the production base of industrial housing, creating long-term conditions for sustainable development of enterprises and enhancing their competitiveness, green growth of the construction industry and the Russian economy as a whole.

\section{CONCLUSION}

Until recently, there has not been a generally accepted conceptual framework in this area, which hinders the development of the principles of resource and energy saving in the construction industry, particularly in the building materials industry. The development of theoretical approaches will provide the scientific basis for the management of energy innovation, improve regulatory support in this area, establish adequate mechanisms in order to promote the process of development and implementation of energy and environmental innovation. 


\section{ACKNOWLEDGMENT}

The present research has been supported by the Russian Humanitarian Scientific Fund $(R G N F)$ within the project "Development of Ecological-Economic Methods of Energy Innovation Management in the Building Materials Industry" No. 15-32-01383; the project "The Methodology and Formation of the Economic Mechanism on the Elimination of Accumulated Environmental Damage in the Russian Federation" No. 15-02-00141; the project "Development of Innovative Mechanism for the Use of Resources of Technogenic Deposits for Production of Construction Materials (by the example of mining enterprises in Russia and Mongolia)" No. 15-22-03003.

\section{REFERENCES}

Basic directions of activity of the Russian Federation Government for the period until 2018: Decree of the Russian Federation Government (2013, Jan. 31).

Kuzina O. (2014, April). Building materials industry as the basis of formation of the construction industry products. In materials of IVth international scientific-practical conference "Modern problems of project management in investment and construction sphere and environmental management", (pp. 93-99). Moscow, Russian Federation.

Kuzina O. (2014, July). "Green" construction and main directions of modernization of the building materials industry. In materials of IVth international scientific-practical conference "Problems of safe development of modern society", (pp. 154-157). Ekaterinburg, Russian Federation.

Kuzina O. (2014, April). The situation of building materials industry enterprises on the modern stage of development of economy of the Russian Federation. In materials of Scientific-practical conference "Economic problems of sustainable development", (pp. 179-180). Sumy, Ukraine.

Kuzina O. (2015, June). The development of the building materials industry on the basis of energy-saving innovations in the Russian Federation. In materials of International scientificpractical conference "Options for development and innovation in pedagogy, economics, law, cultural studies and sociology", (pp. 90-93). Volgograd, Russian Federation.

Kuzina O. (2015, April). The features of functioning and development of building materials industry enterprises of Moscow. In materials of Vth international scientific-practical conference "Modern problems of project management in investment and construction sphere and environmental management", (pp. 47-52). Moscow, Russian Federation.

Research initiatives. Retrieved June 14, 2015 from the Information construction portal website, http://www.stroyinform.ru.

Research initiatives. Retrieved July 14, 2014 from the Russian classifier of types of economic activity, Federal state statistics service website, http://www.gks.ru/metod/classifiers.html.

Research initiatives. Retrieved June 10, 2014 from the Ministry of regional development of the Russian Federation website, http://old.minregion.ru/press_office/news/2582.html.

The strategy of development of the building materials industry and industrial construction for the period till 2020: Decree of the Ministry of regional development of the Russian Federation (2011, May 30).

\section{AUTHORS' SHORT BIOGRAPHY}

Olga V. Kuzina is a Candidate of Economic Sciences, Associate Professor of the Department of Project and Program Management. The degree of Candidate of Economic Sciences was obtained in 2011 from Plekhanov Russian University of Economics, speciality "Economy and Management of National Economy (Construction)". The author has 18 publications. The area of scientific interests is energy saving in the construction industry, energy innovations, building materials industry, project management. She is the Head of the grant of the Russian Humanitarian Scientific Fund No. 15-32-01383, the project "Development of Ecological-Economic Methods of Energy Innovation Management in the Building Materials Industry", and a member of grants No. 15-0200141, No. 15-22-03003. 